\title{
Pengaruh Ekspektasi Kinerja, Ekspektasi Usaha dan Faktor Sosial terhadap Penggunaan Sistem Informasi Akuntansi (Studi Kasus Pada Minimarket di Kota Tegal)
}

\author{
Sistem Informasi Akuntansi \\ Lestari Ayu Handayani $^{1)}$, Tabrani $^{2)}$, Dewi Indriasih ${ }^{3)}$ \\ Fakultas Ekonomi dan Bisnis, Universitas Pancasakti, Tegal \\ lestaria239@gmail.com, tabrani12@yahoo.co.id, dewi.indriasih@gmail.com
}

\begin{abstract}
The purpose of this study was to examine the effect of performance expectations, business expectations and social factors on the use of accounting information systems at minimarkets in Tegal City. This research is a type of correlational research with a quantitative approach. The population used in this study is 100 minimarkets in Tegal City. The sampling method used is Convenience sampling, which is a sampling technique that is a collection of information from members of the population that is easily obtained and able to provide that information with the number of samples calculated using the Slovin formula. The type of data used is qualitative data. The technique of data collection is done by questionnaire technique. The variables of this study consisted of performance expectations (X1), business expectations (X2), social factors (X3) as independent variables, and accounting information systems $(Y)$ as dependent variables, with ordinal measurement scales. The analytical method used in this study is descriptive analysis, classic assumption test, multiple regression analysis, $F$ test, $t$ test and coefficient of determination. The results of this study are partially performance expectations and social factors have a significant effect on accounting information systems, but business expectations do not affect accounting information systems.
\end{abstract}

Keywords : Performance Expectancy, Effort Expectancy, and Social Facto

\begin{abstract}
ABSTRAK
Tujuan dari penelitian ini adalah menguji pengaruh ekspektasi kinerja, ekspektasi usaha dan faktor sosial terhadap penggunaan sistem informasi akuntansi pada minimarket yang berada di Kota Tegal. Penelitian ini merupakan jenis penelitian korelasional dengan pendekatan kuantitatif. Populasi yang digunakan dalam penelitian ini adalah 100 minimarket di Kota Tegal. Metode pengambilan sampel yang digunakan adalah Convenience sampling, yaitu teknik sampling yang sebagai kumpulan informasi dari anggota-anggota populasi yang mudah diperoleh dan mampu menyediakan informasi tersebut dengan jumlah sampel dihitung dengan menggunakan rumus slovin. Jenis data yang digunakan adalah data kualitatif. Teknik pengumpulan data dilakukan dengan cara teknik kuesioner. Variabel penelitian ini terdiri dari ekspektasi kinerja (X1), ekspektasi usaha (X2), faktor sosial (X3) sebagai variabel independen, dan sistem informasi akuntansi (Y) sebagai variabel dependen, dengan skala pengukuran ordinal. Metode analisis yang digunakan dalam penelitian ini adalah analisis deskriptif, uji asumsi klasik, analisis regresi berganda, uji F, uji t dan koefisien determinasi. Hasil penelitian ini adalah secara parsial ekspektasi kinerja dan faktor sosial berpengaruh
\end{abstract}


signifikan terhadap sistem informasi akuntansi, akan tetapi ekspektasi usaha tidak berpengaruh terhadap sistem informasi akuntansi

\section{Kata Kunci : Ekspektasi Kinerja, Ekspektasi Usaha dan Faktor Sosial.}

\section{Pendahuluan}

Salah satu bentuk pembangunan pada sektor ekonomi adalah munculnya toko modern atau yang biasa disebut dengan minimarket. Toko modern atau minimarket adalah toko dengan sistem pelayanan mandiri yang menjual berbagai jenis barang secara eceran. Minimarket saat ini semakin marak di Indonesia, terlebih lagi dengan adanya jaringan minimarket dengan sistem franchise atau waralaba (Saraswati, 2017).

Produk yang diperjual belikan dalam minimarket juga lebih banyak sekitar 5000 item. Banyaknya produk yang dijual juga bertujuan agar dapat memenuhi kebutuhan fungsional konsumen sekaligus dengan kebutuhan psikologi. Semakin kompleknya kegiatan dalam suatu usaha tersebut maka diperlukan manajemen yang baik selain itu juga memerlukan pengawasan dan pengendalian pada bisnis yang dijalankan tersebut. Dengan besarnya peranan dari bisnis minimarket karena menjadi salah satu penggerak roda perekonomian maka diperlukan melakukan peningkatan kinerja dan daya saing. Usaha tersebut dilakukan agar terjaganya stabilitas perekonomian, salah satunya dengan menggunakan dan menerapkan penggunaan informasi akuntansi. Perusahaan yang memiliki sistem informasi akuntansi berbasis komputer memiliki keunggulan tersendiri untuk bersaing (Whetyningtyas, 2016).

Sistem informasi akuntansi merupakan sebuah sistem informasi yang dibuat khusus untuk mempermudah kegiatan segala sesuatu yang berkaitan dengan akuntansi. Informasi akuntansi memiliki peranan penting untuk mencapai keberhasilan usaha. Informasi akuntansi dapat menjadi dasar bagi pengambilan suatu keputusan ekonomis dalam memecahkan permasalahan yang terdapat pada suatu pengelolaan usaha. Penyediaan sistem informasi akuntansi bagi bisnis minimarket juga diperlukan khususnya untuk kecepatan dan keakuratan dalam setiap transaksi penjualan dan pembelian. Dengan adanya sistem informasi akuntansi sendiri dapat melakukan proses operasi maupun informasi dengan lebih efektif dan efisien (Mardi, 2016)

Sejauh ini permasalahan yang dihadapi oleh bisnis minimarket di Kota Tegal diantaranya adalah masih banyaknya penggunaan sistem yang error. Kejadiaan sistem yang error ini dapat berakibat pengecekan stok barang dan proses transaksi dapat terhambat. Selain itu juga ketika sistem error komunikasi mengenai keuangan yang dilakukan melalui sistem informasi akutansi kepada pihak-pihak terkait yang berupa laporan-laporan kegiatan menjadi terganggu dan dapat terjadi penyelewengan (Sukerti, 2017). Dengan terjadinya penyelewengan tersebut namun masih ada pemilik atau pengelola minimarket yang beranggapan bahwa penerapan sistem informasi akuntansi tidak terlalu di butuhkan karena usaha yang dijalankan bukan usaha besar. Kurangnya pengetahuan dari pemilik bisnis terhadap akuntansi, pendapatan tidak tetap dan ada juga yang beranggapan bahwa akuntansi terlalu rumit untuk diterapkan juga menjadi latar belakang dari kurang diterapkanya sistem informasi akuntansi pada usaha tersebut (Rahman dan Suhartati, 2012).

Pemilik atau pengelola minimarket di Kota Tegal masih belum sadar bahwa sistem informasi akuntansi merupakan aspek manajemen untuk menciptakan bisnis yang sehat sekecil apapun data keuangan yang diperoleh. Terjadinya kecurangan dalam laporan keuangan juga dapat dikendalikan oleh perusahaan tersebut, bentuk pengendalian adalah terhadap sistem dan prosedur akuntansi. Untuk itu manfaat adanya sistem informasi akuntansi ada pada bisnis minimarket ini dapat mebantu dalam kelancaran tugas dan cara mudah dalam koordinasi antar bagian yang ada (Baridwan, 2009). 
Terdapat beberapa faktor yang harus dianalis berhubungan dengan penggunaan sistem informasi akuntansi pada bisnis minimarket. Faktor-faktor yang mempengaruhi dalam penggunaan sistem informasi ada tiga. Yang pertama adalah ekspektasi kinerja. Definisi kinerja perusahaan sendiri adalah hasil kerja yang telah dicapai suatu perusahaan dalam melaksanakan tugas sesuai dengan tanggung jawab yang diberikan (Suryaputri, 2012). Sistem informasi akuntansi diperlukan untuk mengukur sejauh mana hasil kerja yang telah dicapai oleh suatu perusahaan. Maka dari itu ekspektasi kinerja memiliki arti sebagai tingkat keyakinan individu bahwa dengan menggunakan suatu sistem informasi akan meningkatkan produktivitas dan efektivitas suatu usaha. Hubungan antara ekspektasi kinerja dengan penggunaan sistem informasi akuntansi adalah ketika perusahaan menggunakan sistem informasi akuntansi maka mengatur kegiatan operasional perusahaan, sumber daya perusahaan dan pembuatan strategi dalam perusahaan akan terlaksana dengan baik yang mengakibatkan meningkatnya kinerja dalam perusahaan tersebut. Dengan kata lain ketika semakin tinggi kinerja dalam suatu perusahaan maka akan semakin tinggi penggunaan sistem informasi akuntansi yang digunakan (Savitri dan Wiratmaja, 2015).

Ekspektasi usaha adalah suatu kemudahan yang dapat diperoleh ketika menggunakan sistem informasi (Sekraini dan Meiranto, 2014). Semakin mudah sistem yang digunakan maka akan semakin mengurangi upaya individu dalam melakukan suatu pekerjaan. Hubungan antara penggunaan sistem informasi akuntansi dengan ekspektasi usaha adalah ketika individu telah mendapatkan kemudahan dan merasa dengan menggunakan sistem informasi akuntansi memiliki banyak manfaat maka akan memunculkan rasa ketergantungan dan kenyamanan yang membuat individu tersebut akan terus menggunakan sistem informasi akuntansi. Dengan perusahaan menggunakan sistem informasi akuntansi dapat membuat pekerjaan yang dilakukan menjadi efektif dan efisien dan tercapainya tujuan dari perusahaan itu sendiri (Savitri dan Wiratmaja, 2015).

Faktor terakhir yang mempengaruhi penggunaan sistem informasi yaitu faktor sosial. Faktor sosial memiliki arti bahwa pengaruh dari orang-orang disekitar untuk meyakinkan individu menggunakan suatu sistem informasi (Rosita, 2013). Hubungan antara faktor sosial dengan penggunaan sistem informasi akuntansi adalah semakin besar dukungan teman kantor, manajer, pimpinan serta organisasi maka akan semakin mempengaruhi individu untuk mengunakan sistem informasi akuntansi (Suryaputri, 2012).

\section{Perumusan Masalah}

Permasalahan yang dikemukakan dalam penelitian ini adalah sebagai berikut.

1. Apakah terdapat pengaruh ekspektasi kinerja secara parsial terhadap penggunaan sistem informasi akuntansi pada minimarket di Kota Tegal ?

2. Apakah terdapat pengaruh ekspektasi usaha secara parsial terhadap penggunaan sistem informasi akuntansi pada minimarket di Kota Tegal ?

3. Apakah terdapat pengaruh faktor sosial secara parsial terhadap penggunaan sistem informasi akuntansi pada minimarket di Kota Tegal ?

Tujuan Penelitian

1. Untuk mengetahui pengaruh ekspektasi kinerja secara parsial terhadap penggunaan sistem informasi akuntansi pada minimarket di Kota Tegal.

2. Untuk mengetahui pengaruh ekspektasi usaha secara parsial terhadap penggunaan sistem informasi akuntansi pada minimarket di Kota Tegal.

3. Untuk mengetahui pengaruh faktor sosial secara parsial terhadap penggunaan sistem informasi akuntansi pada minimarket di Kota Tegal. 


\section{Kerangka Pemikiran dan Hipotesis}

2.1 Kerangka Pemikiran

Adapun kerangka pemikiran dalam penelitian ini adalah sebagai berikut :

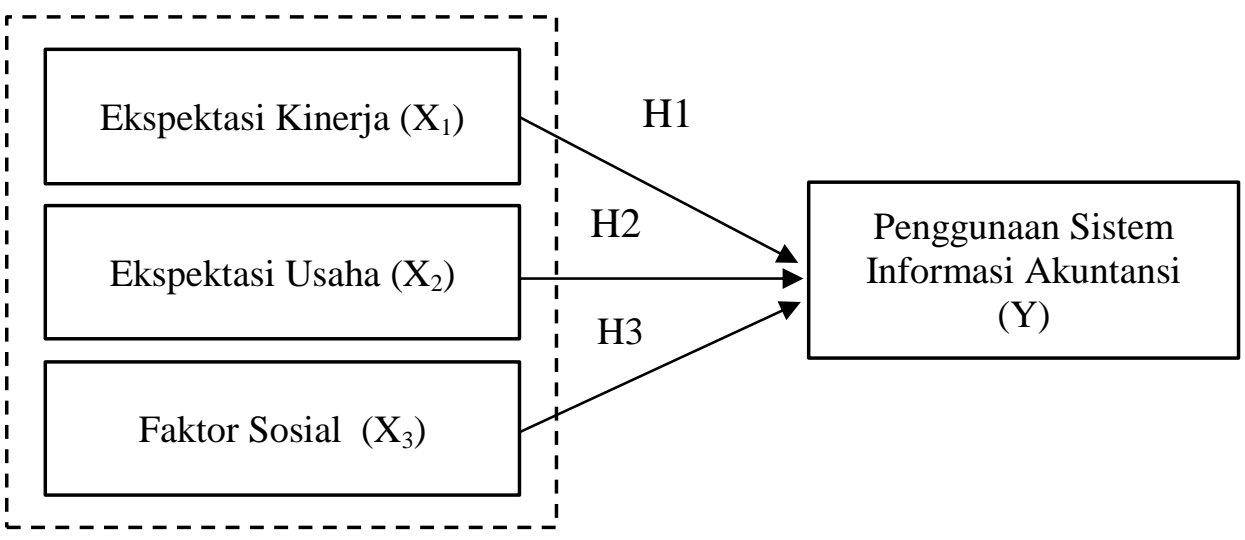

\subsection{Hipotesis}

- Pengaruh ekspektasi kinerja secara parsial terhadap penggunaan sistem informasi akuntansi pada minimarket di Kota Tegal.

Ekspektasi kinerja adalah tingkat keyakinan individu bahwa dengan menggunakan suatu sistem informasi akan meningkatkan produktivitas dan efektivitas suatu usaha (Savitri dan Wiratmaja, 2015). Sistem informasi akuntansi sangat membantu untuk mengatur sumber daya perusahaan, mengatur kegiatan operasional perusahaan dan pembuatan strategi dalam perusahaan. Menurut Handayani (2016) bahwa ekspektasi kinerja memiliki pengaruh terhadap penggunaan sistem informasi akuntansi. Dikarenakan dengan adanya sistem informasi akuntansi ini dalam perusahaan maka akan meningkatkan suatu kinerja.

H1 : Ekspektasi kinerja berpengaruh terhadap penggunaan sistem informasi akuntansi

- Terdapat pengaruh ekspektasi usaha secara parsial terhadap penggunaan sistem informasi akuntansi pada minimarket di Kota Tegal.

Ekspektasi usaha adalah suatu kemudahan yang dapat diperoleh ketika menggunakan sebuah sistem informasi. Menurut Savitri dan Wiratmaja (2015) semakin individu mendapatkan kemudahan ketika menggunakan sistem informasi akuntansi maka akan semakin menimbulkan rasa nyaman dan membuat individu menjadi ketergantungan untuk terus menerus menggunakan sistem informasi akuntansi tersebut. Hal ini menunjukan bahwa ekspektasi usaha memiliki pengaruh terhadap penggunaan sistem informasi akuntansi karena mempunyai nilai kegunaan bagi individu (Sekarini dan Meiranto, 2014). Sehingga dengan menggunakan sistem informasi akuntansi ini pekerjaan individu akan menjadi lebih efektif dan efisien serta dapat tercapainya tujuan perusahaan dari pada dengan cara manual.

$\mathrm{H} 2$ : Ekspektasi usaha berpengaruh terhadap penggunaan sistem informasi akuntansi

- Terdapat pengaruh faktor sosial secara parsial terhadap penggunaan sistem informasi akuntansi pada minimarket di Kota Tegal.

Faktor sosial adalah pengaruh dari orang-orang disekitar untuk menggunakan sistem informasi. Menurut Sekarini dan Meiranto (2014) mengatakan bahwa semakin besar dukungan dari lingkungan disekitar individu seperti teman sekantor, manajer, pemipin atau suatu organisasi maka akan semakin besar pula penggunaan sistem informasi akuntansi. Untuk itu individu tidak akan pernah bisa terlepas dari lingkungan sosialnya karena setiap saat individu akan melakukan interaksi sosial. Dari interaksi 
sosial ini yang dapat mempengaruhi suatu pola fikir individu lain untuk mau menggunakan suatu sistem informasi akuntansi. Hal ini menunjukan bahwa faktor sosial berpengaruh terhadap penggunaan sistem informasi akuntansi (Handayani, 2016).

H3 : Faktor sosial berpengaruh terhadap penggunaan sistem informasi akuntansi

\section{Metode Penelitian}

Jenis penelitian yang digunakan dalam penelitian ini termasuk dalam jenis penelitian kuantitatif. Penelitian ini menggunakan data kualitatif yang berupa kuesioner yang akan dijabarkan dalam sebuah angka jawaban responden, sehingga data tersebut ketika diolah berubah menjadi data kuantitatif. Adapun menurut kegiatan penelitian termasuk jenis penelitian korelasional. Populasi pada penelitian ini adalah 100 pengelola atau karyawan minimarket di Kota Tegal. Teknik pengambilan sampel adalah Convenience sampling, dengan menggunakan rumus slovin. Variabel yang akan diteliti pada penelitian ini meliputi antara lain ekspektasi kinerja, ekspektasiu usaha dan faktor sosial, penggunaan sistem informasi akuntansi. Variabel dependen dalam penelitian ini adalah penggunaan sistem informasi akuntansi. Sedangkan variabel independen adalah ekspektasi kinerja, ekspektasi usaha dan faktor sosial.

Uji instrumen yang digunakan dalam penelitian ini adalah uji validitas dan uji realibilitas. Sedangkan teknik analisis data yang digunakan pada penelitian ini adalah analisis deskriptif, uji asumsi klasik, analisis regresi berganda, uji hipotesis $\mathrm{F}$, uji hipotesiss $\mathrm{T}$ dan koefisien determinasi.

\section{Hasil}

Berdasarkan hasil data yang dikumpulkan dengan metode pengumpulan data peroleh deskripsi data tentang variabel penelitian seperti pada tabel berikut :

\subsection{Uji Instrumen Penelitian}

a. Uji Validitas

1. Uji Validitas Ekspektasi Kinerja

Hasil Uji Validitas Variabel Ekspektasi Kinerja

\begin{tabular}{|c|c|c|c|}
\hline Variabel & $\begin{array}{c}\text { Item } \\
\text { Pertanyaan }\end{array}$ & $\begin{array}{c}\text { Pearson } \\
\text { Corelation }\end{array}$ & Status \\
\hline \multirow{4}{*}{$\begin{array}{c}\text { Ekspektasi } \\
\text { Kinerja }\end{array}$} & EK1 & 0,402 & Valid \\
\cline { 2 - 4 } & EK2 & 0,756 & Valid \\
\cline { 2 - 4 } & EK3 & 0,531 & Valid \\
\cline { 2 - 4 } & EK4 & 0,642 & Valid \\
\cline { 2 - 4 } & EK5 & 0,617 & Valid \\
\cline { 2 - 4 } & EK6 & 0,774 & Valid \\
\cline { 2 - 4 } & EK8 & 0,604 & Valid \\
\cline { 2 - 4 } & EK9 & 0,469 & Valid \\
\cline { 2 - 4 } & EK10 & 0,459 & Valid \\
\cline { 2 - 4 } & EK11 & 0,437 & Valid \\
\cline { 2 - 4 } & EK12 & 0,732 & Valid \\
\hline
\end{tabular}

Berdasarkan Tabel maka dapat dilihat bahwa keseluruhan pertanyaan untuk variabel ekspektasi kinerja memiliki status valid, karena nilai $r_{\text {hitung }}$ (Corrected ItemTotal Correlation) $>r_{\text {tabel }}$ sebesar 0,235.

2. Uji Validitas Ekspektasi Usaha 
Hasil Uji Validitas Variabel Ekspektasi Usaha

\begin{tabular}{|c|c|c|c|}
\hline Variabel & $\begin{array}{c}\text { Item } \\
\text { Pertanyaan }\end{array}$ & $\begin{array}{c}\text { Pearson } \\
\text { Corelation }\end{array}$ & Status \\
\hline \multirow{4}{*}{$\begin{array}{c}\text { Ekspektasi } \\
\text { Usaha }\end{array}$} & EU1 & 0,379 & Valid \\
\cline { 2 - 4 } & EU2 & 0,572 & Valid \\
\cline { 2 - 4 } & EU3 & 0,378 & Valid \\
\cline { 2 - 4 } & EU4 & 0,402 & Valid \\
\cline { 2 - 4 } & EU5 & 0,681 & Valid \\
\cline { 2 - 4 } & EU6 & 0,466 & Valid \\
\cline { 2 - 4 } & EU7 & 0,346 & Valid \\
\cline { 2 - 4 } & EU8 & 0,306 & Valid \\
\cline { 2 - 4 } & EU9 & 0,736 & Valid \\
\cline { 2 - 4 } & EU10 & 0,415 & Valid \\
\cline { 2 - 4 } & EU11 & 0,664 & Valid \\
\cline { 2 - 4 } & EU12 & 0,465 & Valid \\
\hline
\end{tabular}

Berdasarkan Tabel maka dapat dilihat bahwa keseluruhan pertanyaan untuk variabel ekspektasi usaha memiliki status valid, karena nilai $r_{\text {hitung }}$ (Corrected ItemTotal Correlation) $>r_{\text {tabel }}$ sebesar 0,235.

3. Uji Validitas Faktor Sosial

Hasil Uji Validitas Variabel Faktor Sosial

\begin{tabular}{|c|c|c|c|}
\hline Variabel & $\begin{array}{c}\text { Item } \\
\text { Pertanyaan }\end{array}$ & $\begin{array}{c}\text { Pearson } \\
\text { Corelation }\end{array}$ & Status \\
\hline \multirow{4}{*}{ Faktor Sosial } & FS1 & 0,760 & Valid \\
\cline { 2 - 4 } & FS2 & 0,646 & Valid \\
\cline { 2 - 4 } & FS3 & 0,563 & Valid \\
\cline { 2 - 4 } & FS4 & 0,513 & Valid \\
\cline { 2 - 4 } & FS5 & 0,724 & Valid \\
\cline { 2 - 4 } & FS6 & 0,618 & Valid \\
\cline { 2 - 4 } & FS7 & 0,578 & Valid \\
\cline { 2 - 4 } & FS8 & 0,494 & Valid \\
\cline { 2 - 4 } & FS9 & 0,572 & Valid \\
\cline { 2 - 4 } & FS10 & 0,591 & Valid \\
\cline { 2 - 4 } & FS11 & 0,320 & Valid \\
\cline { 2 - 4 } & FS12 & 0,504 & Valid \\
\hline
\end{tabular}

Berdasarkan Tabel maka dapat dilihat bahwa keseluruhan pertanyaan untuk variabel faktor sosial memiliki status valid, karena nilai $r_{\text {hitung }}$ (Corrected Item-Total Correlation) $>r_{\text {tabel }}$ sebesar 0,235 . 
4. Uji Validitas Sistem Informasi Akuntansi

Hasil Uji Validitas Variabel Sistem Informasi Akuntansi

\begin{tabular}{|c|c|c|c|}
\hline Variabel & $\begin{array}{c}\text { Item } \\
\text { Pertanyaan }\end{array}$ & $\begin{array}{c}\text { Pearson } \\
\text { Corelation }\end{array}$ & Status \\
\hline \multirow{4}{*}{$\begin{array}{c}\text { Sistem } \\
\text { Informasi }\end{array}$} & SIA1 & 0,406 & Valid \\
\cline { 2 - 4 } & SIA2 & 0,510 & Valid \\
\cline { 2 - 4 } & SIA3 & 0,399 & Valid \\
\cline { 2 - 4 } & SIA4 & 0,749 & Valid \\
\cline { 2 - 4 } & SIA5 & 0,711 & Valid \\
\cline { 2 - 4 } & SIA6 & 0,553 & Valid \\
\cline { 2 - 4 } & SIA7 & 0,570 & Valid \\
\cline { 2 - 4 } & SIA8 & 0,393 & Valid \\
\cline { 2 - 4 } & SIA9 & 0,584 & Valid \\
\cline { 2 - 4 } & SIA10 & 0,557 & Valid \\
\cline { 2 - 4 } & SIA11 & 0,537 & Valid \\
\cline { 2 - 4 } & SIA12 & 0,520 & Valid \\
\hline
\end{tabular}

Berdasarkan Tabel maka dapat dilihat bahwa keseluruhan pertanyaan untuk variabel sistem informasi akuntansi memiliki status valid karena nilai $r_{\text {hitung }}$ (Corrected Item-Total Correlation) $>r_{\text {tabel }}$ sebesar 0,235.

b. Uji Realibilitas

Hasil Uji Reliabilitas Variabel Penelitian

\begin{tabular}{|l|c|c|}
\hline \multicolumn{1}{|c|}{ Variabel } & $\begin{array}{c}\text { Jumlah } \\
\text { Item }\end{array}$ & $\begin{array}{c}\text { Cronbach } \\
\text { Alpha }\end{array}$ \\
\hline $\begin{array}{l}\text { Sistem Informasi } \\
\text { Akuntansi }\end{array}$ & 12 & 0,784 \\
\hline Ekspektasi Kinerja & 12 & 0,809 \\
\hline Ekspektasi Usaha & 12 & 0,690 \\
\hline Faktor Sosial & 12 & 0,809 \\
\hline
\end{tabular}

Berdasarkan tabel dapat diketahui bahwa nilai Cronbach Alpha masing-masing instrumen yang digunakan dalam penelitian ini adalah > 0,60 yang mengisyaratkan bahwa data yang dikumpulkan dengan menggunakan instrumen tersebut reliabel.

\subsection{Teknik Analisis Data}

A. Analisis Deskriptif

Descriptive Statistics

\begin{tabular}{|l|r|r|r|r|r|}
\hline & \multicolumn{1}{|c|}{ N } & \multicolumn{1}{|c|}{ Minimum } & Maximum & Mean & Std. Deviation \\
\hline EkspektasiKinerja & 50 & 27 & 60 & 46,04 & 5,360 \\
EkspektasiUsaha & 50 & 31 & 51 & 40,26 & 4,881 \\
FaktorSosial & 50 & 32 & 54 & 43,64 & 5,982 \\
PenggunaanSIA & 50 & 32 & 55 & 46,68 & 5,032 \\
Valid N (listwise) & 50 & & & & \\
\hline
\end{tabular}


Berdasarkan persamaan regresi berganda tersebut dapat diambil analisis sebagai berikut :

1. Hasil analisis diatas menunjukkan bahwa ekspektasi kinerja dengan jumlah obsevasi (N) sebanyak 50 responden. Dari keseluruhan observasi yang telah di lakukan, telah di dapatkan bahwa nilai minimum sebasar 27 dan nilai maksimum sebesar 60. Dengan nilai rata-rata (mean) sebesar 46,04 dengan standar devisiasi sebesar 5,360.

2. Hasil analisis diatas menunjukkan bahwa eksektasi usaha dengan jumlah obsevasi (N) sebanyak 50 responden. Dari keseluruhan observasi yang telah di lakukan, telah di dapatkan bahwa nilai minimum sebasar 31 dan nilai maksimum sebesar 51. Dengan nilai rata-rata (mean) sebesar 40,26 dengan standar devisiasi sebesar 4,881.

3. Hasil analisis diatas menunjukkan bahwa faktor sosial dengan jumlah obsevasi (N) sebanyak 50 responden. Dari keseluruhan observasi yang telah di lakukan, telah di dapatkan bahwa nilai minimum sebesar 32 dan nilai maksimum sebesar 54 . Dengan nilai rata-rata (mean) sebesar 43,64 dengan standar devisiasi sebesar 5,982.

4. Hasil analisis diatas menunjukkan bahwa penggunaan sistem informasi akuntansi dengan jumlah obsevasi $(\mathrm{N})$ sebanyak 50 responden. Dari keseluruhan observasi yang telah di lakukan, telah di dapatkan bahwa nilai minimum sebasar 32 dan nilai maksimum sebesar 55. Dengan nilai rata-rata (mean) sebesar 46,68 dengan standar devisiasi sebesar 5,032.

\section{b. UJI ASUMSI KLASIK}

1.Uji Normalitas

One-Sample Kolmogorov-Smirnov Test

\begin{tabular}{|ll|r|}
\hline & & \multicolumn{2}{|c|}{$\begin{array}{c}\text { Unstandardized } \\
\text { Residual }\end{array}$} \\
\hline $\mathrm{N}$ & Mean & 50 \\
Normal &, 0000000 \\
Parameters & Std. Deviation & 3,72756421 \\
Most Extreme & Absolute &, 082 \\
Differences $\quad$ Positive &, 082 \\
& Negative &,- 054 \\
Test Statistic & &, 082 \\
Asymp. Sig. (2-tailed) &, $200^{\mathrm{c}, \mathrm{d}}$ \\
\hline
\end{tabular}

Hasil uji normalitas data pada tabel menunjukan bahwa untuk model regresi diperoleh signifikansi sebesar 0,200. Penelitian ini memiliki nilai residual di atas 0,05, sehingga penulis menyimpulkan bahwa data dalam penelitian ini telah terdistribusi dengan normal.

\section{Uji Multikolinearitas}

Hasil Uji Multikolinearitas

\begin{tabular}{|l|l|l|}
\hline \multirow{2}{*}{ Model } & \multicolumn{2}{|l|}{ Collinearity Statistics } \\
\cline { 2 - 3 } & Tolerance & VIF \\
\hline (Constant) & & \\
EkspektasiKinerja &, 609 & 1,642 \\
EkspektasiUsaha &, 515 & 1,944 \\
FaktorSosial &, 589 & 1,699 \\
\hline
\end{tabular}




\section{a. Dependent Variable: PenggunaanSIA}

Dari tabel dapat diketahui bahwa tidak satupun variabel bebas yang memiliki nilai VIF kurang dari 10 dan nilai Tolerance lebih dari 0,1. Jadi dapat disimpulkan bahwa tidak ada multikolinearitas antar variabel bebas dalam model regresi ini.

c. Analisis Regresi Berganda

Hasil Analisis Regresi Berganda

\begin{tabular}{|l|l|l|l|}
\hline \multirow{2}{*}{\multicolumn{1}{|c|}{ Model }} & \multicolumn{2}{|c|}{ Unstandardized Coefficients } & $\begin{array}{c}\text { Standardized } \\
\text { Coefficients }\end{array}$ \\
\cline { 2 - 4 } & \multicolumn{1}{|c|}{$\mathrm{B}$} & \multicolumn{1}{|c|}{ Std. Error } & \multicolumn{1}{c|}{ Beta } \\
\hline (Constant) & 17,250 & 5,305 & \\
Ekspektasi Kinerja &, 526 &, 131 &, 560 \\
Ekspektasi Usaha &,- 145 &, 157 &,- 141 \\
Faktor Sosial &, 254 &, 120 &, 302 \\
\hline
\end{tabular}

Berdasarkan tabel dapat dilihat nilai konstanta sebesar 17,250, variabel ekpektasi kinerja sebesar 0,526 , ekspektasi usaha $-0,145$ dan faktor sosial sebesar 0,254. Sehingga dapat diperoleh persamaan regresi yaitu :

$$
\mathrm{Y}=17,250+0,526 \mathrm{X}_{1}-0,145 \mathrm{X}_{2}+0,254 \mathrm{X}_{3}+\mathrm{e}
$$

Keterangan :

$\mathrm{X}_{1}$ : Ekspektasi Kinerja

$\mathrm{X}_{2}$ : Ekspektasi Usaha

$\mathrm{X}_{3}$ : Faktor Sosial

e : Error

Berdasarkan persamaan regresi berganda tersebut dapat diambil analisis sebagai berikut :

1. Nilai konstanta sebesar 17,250 menunjukkan bahwa variabel ekspektasi kinerja, ekspektasi usaha dan faktor sosial jika nilainya 0 maka penggunaan sistem informasi akuntansi akan bernilai sebesar 17,250.

2. Nilai koefisien ekspektasi kinerja sebesar 0,526 dengan nilai positif. Hal ini berarti bahwa setiap peningkatan ekspektasi kinerja sebesar 1 kali maka penggunaan sistem informasi akuntansi akan meningkat sebesar 0,526 dengan asumsi variabel yang lain konstan.

3. Nilai koefisien ekspektasi usaha sebesar $-0,145$ dengan nilai negatif. Hal ini berarti bahwa setiap peningkatan ekspektasi usaha sebesar 1 kali maka penggunaan sistem informasi akuntansi akan menurun sebesar - 0,145 dengan asumsi variabel yang lain konstan.

4. Nilai koefisien faktor sosial sebesar 0,245 dengan nilai positif. Hal ini berarti setiap peningkatan faktor sosial sebesar 1 kali maka penggunaan sistem informasi akuntansi akan meningkat sebesar 0,245 dengan asumsi variabel yang lain konstan. 
d. Uji Hipotesis

1. Uji F

Hasil Uji F

\begin{tabular}{|l|l|c|c|}
\hline \multicolumn{1}{|c|}{ Model } & \multicolumn{1}{c|}{ Sum of Squares } & F & Sig. \\
\hline Regression & 560,038 & 12,613 &, $000^{\mathrm{b}}$ \\
Residual & 680,842 & & \\
Total & 1240,880 & & \\
\hline
\end{tabular}

Berdasarkan hasil data di atas maka secara simultan menunjukkan nilai $\mathrm{F}$ sebesar 12,613 dengan signifikansi pengujian sebesar 0,000. Sehingga $0,000<0,05$, yang artinya terdapat pengaruh yang signifikan ekspektasi kinerja, ekspektasi usaha dan faktor sosial secara silmutan terhadap penggunaan sistem informasi akuntansi.

2. Uji $t$

\begin{tabular}{|l|c|c|}
\multicolumn{1}{|c|}{ Hasil Uji t } \\
\hline \multicolumn{1}{|c|}{ Model } & $\mathrm{T}$ & Sig. \\
& & \\
\hline (Constant) & 3,252 &, 002 \\
EkspektasiKinerja & 4,001 &, 000 \\
EkspektasiUsaha &,- 924 &, 360 \\
FaktorSosial & 2,118 &, 040 \\
\hline
\end{tabular}

Berdasarkan hasil pengujian data diatas maka dapat dapat di jelaskan sebagai berikut:

1. Variabel ekspektasi kinerja memiliki nilai t sebesar 4,001 dengan tingkat signifikansi sebesar 0,000 lebih kecil dari taraf singnifikansi 0,05. Maka hal ini menunjukkan bahwa variabel ekspektasi kinerja mempunyai pengaruh positif dan signifikan terhadap sistem informasi akuntansi.

2. Variabel ekspektasi usaha memiliki nilai t sebesar - 0,924 dengan tingkat signifikansi sebesar 0,360 lebih besar dari taraf singnifikansi 0,05. Maka hal ini menunjukkan bahwa variabel ekspektasi usaha mempunyai pengaruh negatif dan tidak signifikan terhadap sistem informasi akuntansi .

3. Variabel faktor sosial memiliki nilai t sebesar 2,118 dengan tingkat signifikansi sebesar 0,040 lebih kecil dari taraf singnifikansi 0,05. Maka hal ini menunjukkan bahwa variabel faktor sosial mempunyai pengaruh positif dan signifikan terhadap sistem informasi akuntansi.

e. Koefisien Determinasi

Hasil Uji Koefisien Determinasi

\begin{tabular}{|l|c|l|l|l|}
\hline Model & $\mathrm{R}$ & $\mathrm{R}$ Square & Adjusted R Square & $\begin{array}{c}\text { Std. Error of the } \\
\text { Estimate }\end{array}$ \\
\hline 1 &, $672^{\mathrm{a}}$ &, 451 &, 416 & 3,847 \\
\hline
\end{tabular}

Berdasarkan tabel di atas dapat besar nilai adjusted $R^{2}$ sebesar 0,416 yang berarti bahwa validitas variabel dependen yang dapat dijelaskan oleh variabel independen yaitu 41,6 $\%$. Hal ini menunjukkan bahwa $41,6 \%$ sistem informasi akuntansi di pengaruhi oleh variabel- 
variabel independen dalam model dan sisanya $58,4 \%$ di pengaruhi oleh variabel lain yang tidak diteliti dalam penelitian ini.

\section{Kesimpulan dan Saran}

5.1. Kesimpulan

Berdasarkan hasil penelitian yang dilakukakn maka dapat diambil beberapa kesimpulan sebagai berikut :

1. Terdapat pengaruh ekspektasi kinerja secara parsial terhadap penggunaan sistem informasi akuntansi, dibuktikan dengan nilai signifikansi sebesar 0,000 lebih kecil dari 0,05.

2. Tidak terdapat pengaruh ekspektasi usaha secara parsial terhadap penggunaan sistem informasi akuntansi, dibuktikan dengan nilai signifikansi sebesar 0,360 lebih besar dari 0,05.

3. Terdapat pengaruh faktor sosial secara parsial terhadap penggunaan sistem informasi akuntansi, dibuktikan dengan nilai signifikansi sebesar 0,040 lebih kecil dari 0,05.

\subsection{Saran}

Berdasarkan kesimpulan dari penelitian ini, maka dapat diberikan beberapa saran sehubungan dengan penelitian ini, yaitu :

1. Ekspektasi kinerja yang ada pada usaha minimarket yang ada di Kota Tegal sangat berpengaruh terhadap penggunaan sistem informasi akuntansi maka hal itu pemilik usaha minimarket perlu memepertahankanya.

2. Ekspektasi usaha yang ada pada usaha mini market di Kota Tegal tidak memiliki pengaruh terhadap penggunaan sistem informasi akuntansi. Hal ini menjadi evaluasi bagi pemilik usaha mini market untuk mengadakanya suatu pelatihan kepada para pegawai agar lebih bisa menggunakan suatu sistem informasi akuntansi.

3. Faktor sosial yang ada pada usaha minimarket di Kota Tegal memiliki pengaruh terhadap penggunaan sistem informasi akuntansi. Untuk itu pemilik usaha minimarket di Kota Tegal perlu mempertahankan ataupun meningkatkanya.

4. Peneliti selanjutnya dapat menambahkan variabel yang lebih luas sehingga mampu mencerminkan faktor-faktor yang mempengaruhi penggunaan sistem informasi akuntansi secara keseluruhan.

5. Penelitian mendatang perlu memperluas implikasi teoritis dengan menghubungkan variabel dependen dengan penggunaan sistem informasi akuntansi atau menambah jumlah variabel yang berpotensi mempengaruhi penggunaan sistem informasi akuntansi. 


\section{DAFTAR PUSTAKA}

Arikunto, Suharsimi. 2014. Prosedur Penelitian Suatu Pendekatan Praktik. Cetakan kesatu. Jakarta: Rineka Cipta.

Ardana, I. Cenik dan Hendro Lukman. 2016. Sistem Informasi Akuntansi. Edisi Pertama. Jakarta: Mitra Wacana Media.

Baridwan, Zaki. 2013. Sistem Informasi Akuntansi. Edisi Kedua. Yogyakarta: BPFE.

Emzir.. 2009. Metodologi Penelitian Kualitatif Dan Kuantitatif. Edisi Pertama. Jakarta: PT Raja Grafindo Pergoda

Fiddin, Fachroh Kamaliah dan Hardi. 2016. "Faktor-Faktor Yang Mempengaruhi Minat Pemanfaatan Sistem Informasi Dan Penggunaan Sistem Informasi (Studi pada Satuan Kerja Perangkat Daerah Pemerintah Provinsi Riau). "Jurnal Sorot. Volume 8. Nomer 1. Tahun 2016.

Fraenkel J.R dan Wallen, N.E. 2008. How To Design And Evaluate Research In Education. New York: McGraw-Hill

Ghozali, Imam. 2016. Aplikasi Analisis Multivariate Dengan Program IBM SPSS 23. Cetakan kedua. Semarang: BPFE Universitas Diponegoro.

Handayani, Rini. 2016. “Analisis Faktor-Faktor Yang Mempengaruhi Minat Pemanfaatan Sistem Informasi Dan Penggunaan Sistem Informasi (Studi pada Perusahaan Manufaktur Di Bursa Efek Indonesia.” Jurnal Akuntansi Dan Keuangan . Volume 9. Nomer 2. Tahun 2016.

Jogiyanto. 2007. Model Kesuskesan Sistem Teknologi Informasi. Edisi Pertama. Yogyakarta: Andi Offset.

Krismiaji. 2015. Sistem Informasi Akuntansi. Edisi Keempat. Yogyakarta: UPP STIM YKPN.

Kusrini dan Andri Koniyo. 2010. Tuntutan Praktis Membangun Sistem Informasi Akuntansi Dengan Visual Basic Dan Microsoft SQL Server odel. Edisi Pertama. Yogyakarta: Andi Offset.

Lestari, Baiq Anggun Hilendry dan Zulaikha. 2007. “ Pengaruh Information Technology Relatedness Terhadap Kinerja Perusahaan Dengan Knowledge Management Capability Sebagai Variabel Intervening (Kajian Empiris Pada Perushaan Perbankan Di Jawa Tengah). " Simposium Nasional Akuntansi X Makassar. Volume 9. Nomer 3. Tahun 2007.

Mardi. 2016. Sistem Informasi Akuntansi. Cetakan Ketiga. Bogor: Ghalia Indonesia

Martinus, Handy. 2009. “ Analisis Industri Retail Nasional.” Jurnal Ekonomi Bisnis. Volume 10. Nomer 7 Tahun 2009

Megawati, Yenli. 2015. “Pertumbuhan Minimarket Sebagai Salah Satu Bentuk Pasar Modern ” Jurnal Ekonomi Bisnis. Volume 15. Nomer 6 Tahun 2015 
Mulyadi. 2016. Sistem Informasi Akuntansi. Cetakan Kedua. Jakarta: Salemba Empat

Rahman, Abdul dan Titi Suhartati. 2012. "Pengaruh Penerapan Sistem Informasi Akuntansi Terhadap UMKM. "Jurnal Ekonomi Bisnis. Volume 11. Nomer 2 Tahun 2012

Rosita. 2013. "Analisis Faktor-Faktor yang Mempengaruhu Minat Penggunaan Sistem Informasi Akuntansi Pada UKM (Studi Empiris Pada UKM di Kabupaten Karanganyar. " GRADUASI. Volume 29. Tahun 2013

Romney, Marshal dan Paul Jhon Steinbart. 2005. Accounting Information System. Edisi Pertama. Jakarta: Salemba Empat.

Saraswati. 2015. " Analisis Dampak Keberadaan Minimarket Indomaret Dan Alfamart Terhadap UKM. " Jurnal Ekonomi Bisnis. Volume 11. Nomer 5. Tahun 2017

Savitri, Ni Made Trisna dan I Dewa Nyoman Wiratmaja. 2015. “ Analisis Faktor-Faktor Yang Mempengaruhi Minat Pemanfaatan Sisrem Informasi Akuntansi. "Jurnal Akuntansi Universitas Udayana. Volume 12. Nomer 3. Tahun 2015

Sekaran, Uma. 2015. Metodologi Penelitian Untuk Bisnis. Buku kesatu. Jakarta: Salemba Empat

Sekaran, Uma. 2015. Metodologi Penelitian Untuk Bisnis. Buku kedua. Jakarta: Salemba Empat

Sekarini, Yunita Ayu dan Wahyu Meiranto. 2014. “Analisis Pengaruh Minat Pemanfaatan Dan Penggunaan Sistem Informasi Terhadap Kinerja Individu Dengan Menggunakan UTAUT Model (Studi Pada PT. Pertamina (persero) UPms IV). " Jurnal Akuntansi Dari Diponegoro. Volume 3. Nomer 1. Tahun 2014.

Siyoto, Sandu dan Ali Sodik. 2015. Dasar Metodologi Penelitian. Cetakan Kesatu. Yogyakarta: Literasi Media Publising.

Sugiyono. 2016. Metode Penelitian Kuantitatif, Kualitatif Dan R\&D. Cetakan Kedua. Bandung: PT Alfabet.

Susanto, Azhar 2017. Sistem Informasi Akuntansi Dan Sistem Informasi Manajemen. Cetakan Pertama. Bandung: Lingga Jaya.

Sukerti, Ni Kadek. 2017. “Implementasi Sistem Informasi Penjualan Untuk Minimarket. " Konferensi Nasional Sistem \& Informatika. Volume 10. Nomer 5 Tahun 2017.

Suryaputri, Rossje V. 2012. “Analisis Faktor-Faktor Yang Mempengaruhi Minat Pemanfaatan Sistem Informasi dan Penggunaan Sistem Informasi Pada Pasar Swalayan (Hypermarket, Supermarket Dan Minimarket) Yang Terdaftar Di Jakarta. "Media Riset Akuntansi, Auditing Dan Informasi. Volume 12. Nomer 2. Tahun2012 
Triandis, H.C. 1980. "Value Attitude And Internasional Behavior, Nebraska Symposium On Motivasion, 1979: Belief, Attitude and Value,” University Of Nebraska Press, Lincoln, NE.

Tritunggal, Winda. 2016. "Faktor-Faktor Yang Mempengaruhi Minat Pemanfaatan Sisrem Informasi Akuntansi. ”Jurnal Akuntansi Universitas PGRI. Volume 10. Nomer 2. Tahun 2016

Umar, Husein. 2013. Desain Penelitian Manajemen. Cetakan Kesatu. Jakarta: Rajawali Pers.

Whetyningtyas, Aprilia. 2016. “Determinan Penggunaan Sistem Informasi Akuntnasi Pada Usaha Kecil Menengah (UKM). "Media Ekonomi Dan Manajemen. Volume 31. Nomer 2. Tahun 2016

Winarno. 2006. Sistem Informasi Akuntansi. Cetakan kesatu. Yogyakarta: UPP STIM YKPN 